\title{
Luminescent complexes containing a gold(I) chromophore with covalently-linked anthracene or pyridinium acceptors
}

\author{
Hong Xiao, ${ }^{a}$ Yu-Xiang Weng, ${ }^{a}$ Shie-Ming Peng ${ }^{b}$ and Chi-Ming Che ${ }^{*, a}$ \\ ${ }^{a}$ Department of Chemistry, The University of Hong Kong, Pokfulam Road, Hong Kong \\ ${ }^{b}$ Department of Chemistry, National Taiwan University, Taipei, Taiwan
}

\begin{abstract}
A series of covalently-linked 'chromophore-quencher' compounds which contain the $\mathrm{Au}(\mathrm{C} \equiv \mathrm{CPh})$ chromophore linked to pyridinium and quaternary ammonium acceptors or anthracene by flexible tethers have been synthesized and subjected to photophysical study in solution; the crystal structure of the anthracene complex has been determined.
\end{abstract}

There has been much interest in the photophysical study of chromophore-quencher molecules with redox-energy-transfer partners arranged in a designed fashion for the purpose of examining the various aspects of electron-energy-transfer reactions. ${ }^{1-3}$ Most of the studies in this area focus on the coordinatively saturated $\mathrm{d}^{6}$ metal--bipyridine chromophores such as ruthenium(II) diimine ${ }^{2}$ and rhenium(I) diimine carbonyl complexes. ${ }^{3}$ In the context of developing new photocatalysts for inner-sphere atom-transfer reactions, it may be advantageous to have a co-ordinatively unsaturated metal-ion chromophore linked to an electron donor-acceptor quencher. Recently, Gray and co-workers ${ }^{4}$ reported an interesting chromophore-quencher system whereby a co-ordinatively unsaturated dinuclear iridium(I) chromophore is covalently linked to pyridinium acceptors. Our recent studies ${ }^{5}$ showed that the excited states of phenylethynylgold(I) complexes with phosphine ancillary ligands are highly reducing and long-lived in solution at room temperature. Herein is described the synthesis and photoredox properties of a series of gold(I) complexes with the $\mathrm{Au}(\mathrm{C} \equiv \mathrm{CPh})$ chromophore covalently linked to anthracene or pyridinium and quaternary ammonium acceptors.

A mixture of $\left[\{\mathrm{Au}(\mathrm{C} \equiv \mathrm{CPh})\}_{\infty}\right](0.1 \mathrm{~g}, 0.33 \mathrm{mmol})$ and $\mathrm{L}^{1}$ or $[\mathrm{L}]\left[\mathrm{BPh}_{4}\right]\left(\mathrm{L}=\mathrm{L}^{2}-\mathrm{L}^{5}\right)(0.3 \mathrm{mmol})$ in dichloromethane $(20$ $\mathrm{cm}^{3}$ ) was stirred under a nitrogen atmosphere for $20 \mathrm{~min}$ at room temperature. The solvent was removed under vacuum and the product was recrystallized by diffusion of diethyl ether into a dichloromethane solution. The ${ }^{31} \mathrm{P}$ NMR spectra of $[\mathrm{Au}(\mathrm{C} \equiv \mathrm{CPh}) \mathrm{L}] \mathrm{BPh}_{4}$ show a solitary singlet at $\delta 136.1-140.1$ which is characteristic of co-ordinated phosphinites.

The crystal structure of $\left[\mathrm{Au}(\mathrm{C} \equiv \mathrm{CPh})\left(\mathrm{L}^{1}\right)\right] \dagger$ has been

$\uparrow$ Crystal data. $\mathrm{C}_{35} \mathrm{H}_{26} \mathrm{AuP}, M=674.56$, monoclinic, space group $P 2_{1} / c, a=9.665(5), b=14.040(4), c=20.249(6) \AA, \beta=91.70(5)^{\circ}$, $U=2746(2) \AA^{3}, D_{\mathrm{c}}=1.631 \mathrm{~g} \mathrm{~cm}^{-3}, Z=4, \mu=54.1 \mathrm{~cm}^{-1}, F(000)=$ 1320. Intensity data were collected on an Enraf-Nonius CAD4 diffractometer with graphite-monochromated Mo-K $\alpha$ radiation $(\lambda=$ $0.7107 \AA) ; 3583$ unique reflections $\left(2 \theta_{\max }=45^{\circ}\right)$ were measured, 2956 of which with $I>2 \sigma(I)$ were used in the refinement. The structure was solved by the Patterson method and refined by least-squares analysis. All computations were performed using the NRCVAX program. ${ }^{6}$ Refinement of positional and anisotropic thermal parameters for all non-hydrogen atoms ( 335 variables) converged to $R=0.028$ and $R^{\prime}=$ 0.023 . The goodness of fit was 2.71 and the weighting scheme $w^{-1}=$ $\sigma^{2}(F)$. The final Fourier-difference map showed residual extrema in the range -0.820 to $0.89 \mathrm{e}^{-3}$. Atomic coordinates, thermal parameters and bond lengths and angles have been deposited at the Cambridge Crystallographic Data Centre (CCDC). See Instructions for Authors, J. Chem. Soc., Dalton Trans., 1996, Issue 1. Any request to the CCDC for this material should quote the full literature citation and the reference number $186 / 150$. determined. As shown in Fig. 1, the $\mathrm{P}-\mathrm{Au}-\mathrm{C} \equiv \mathrm{CPh}$ moiety is close to linearity with the $\mathrm{C}-\mathrm{Au}-\mathrm{P}$ and $\mathrm{Au}-\mathrm{C} \equiv \mathrm{CPh}$ angles being $176.0(2)$ and $175.9(17)^{\circ}$, respectively. The $\mathrm{Au}-\mathrm{P}[2.2664(21)]$ and $\mathrm{Au}-\mathrm{C}[1.999(6) \AA]$ bond distances are comparable to the related values of 2.276(5) and 1.97(2) $\AA$ in $\left[\mathrm{Au}(\mathrm{C} \equiv \mathrm{CPh})\left(\mathrm{PPh}_{3}\right)\right]$. The UV/VIS absorption spectrum of $\left[\mathrm{Au}(\mathrm{C} \equiv \mathrm{CPh})\left(\mathrm{L}^{1}\right)\right](\mathrm{Fig} .2)$ is dominated by three absorption bands: an intense band at 262 $\mathrm{nm}$ with a shoulder at about $285 \mathrm{~nm}$ and a vibronic structured band at $340-410 \mathrm{~nm}$. The $285 \mathrm{~nm}$ absorption compares favourably with the intraligand $\left({ }^{-} \mathrm{C} \equiv \mathrm{CPh}\right)$ and/or metal-toligand charge-transfer transition $\left(\mathrm{Au} \rightarrow{ }^{-} \mathrm{C} \equiv \mathrm{CPh}\right)$ of $[\mathrm{Au}(\mathrm{C} \equiv$ $\left.\mathrm{CPh})\left(\mathrm{PPh}_{3}\right)\right]$ in both energy and absorptivity and is therefore assigned to this transition. The vibronic structured band at 340 $410 \mathrm{~nm}$ is due to the ${ }^{1}\left(\pi \longrightarrow \pi^{*}\right)$ transition of the anthracene moiety. Not surprisingly, the location of the transition for $\left[\mathrm{Au}(\mathrm{C} \equiv \mathrm{CPh})\left(\mathrm{L}^{1}\right)\right]$ is nearly the same as that for the free anthracene. The complexes $[\mathrm{Au}(\mathrm{C} \equiv \mathrm{CPh}) \mathrm{L}] \mathrm{BPh}_{4}\left(\mathrm{~L}=\mathrm{L}^{2}\right.$ $\left.\mathrm{L}^{5}\right) \ddagger$ display intense absorptions at $260-300 \mathrm{~nm}$, which are due to the $\mathrm{Au}(\mathrm{C} \equiv \mathrm{CPh})^{5 a}$ moiety and pyridinum acceptor.

Photoexcitation at $355 \mathrm{~nm}$ of a degassed dichloromethane solution of $\left[\mathrm{Au}(\mathrm{C} \equiv \mathrm{CPh})\left(\mathrm{L}^{1}\right)\right]$ gives an emission at $380-520 \mathrm{~nm}$ (Fig. 2). The well resolved vibronic structure displayed, with peaks at 400,418 and $441 \mathrm{~nm}$, highly resembles the emission of $\mathrm{L}^{1}{ }^{8}$ The emission of $\left[\mathrm{Au}(\mathrm{C} \equiv \mathrm{CPh})\left(\mathrm{L}^{1}\right)\right]$ decays in a biphasic manner, having a fast and a minor slow component with a lifetime of $<20 \mathrm{~ns}$ and $5.2 \mu \mathrm{s}$, respectively. In a dichloromethane solution saturated with oxygen, the lifetime of<smiles>c1ccc(-c2ccccc2CP(c2ccccc2)c2ccccc2)cc1</smiles>

$L^{1}$<smiles>c1ccc(P(OCC[n+]2ccccc2)c2ccccc2)cc1</smiles>

$L^{2}$<smiles>O=[N+]([O-])c1cc[n+](CCCOP(c2ccccc2)c2ccccc2)cc1</smiles>

$\mathrm{L}^{3}$<smiles>CC(C)(C)c1cc[n+](CCOP(c2ccccc2)c2ccccc2)cc1</smiles><smiles>CCN(C)CCCOP(c1ccccc1)c1ccccc1</smiles>

$\mathrm{L}^{5}$

$\ddagger$ UV/VIS $\left(\mathrm{CH}_{2} \mathrm{Cl}_{2}\right): \lambda_{\text {max }} / \mathrm{nm}\left(10^{-4} \varepsilon_{\text {max }} / \mathrm{dm}^{3} \mathrm{~mol}^{-1} \mathrm{~cm}^{-1}\right), 293(1.84)$ and 267 (3.4) for $\left[\mathrm{Au}(\mathrm{C}=\mathrm{CPh})\left(\mathrm{L}^{2}\right)\right], 293(1.03)$ and 265 (1.58) for $\left[\mathrm{Au}(\mathrm{C} \equiv \mathrm{CPh})\left(\mathrm{L}^{3}\right)\right], 293(0.89)$ and $264(1.81)$ for $\left[\mathrm{Au}(\mathrm{C} \equiv \mathrm{CPh})\left(\mathrm{L}^{4}\right)\right]$ and $293(2.22)$ and $268(2.78)$ for $\left[\mathrm{Au}(\mathrm{C} \equiv \mathrm{CPh})\left(\mathrm{L}^{5}\right)\right]$ 


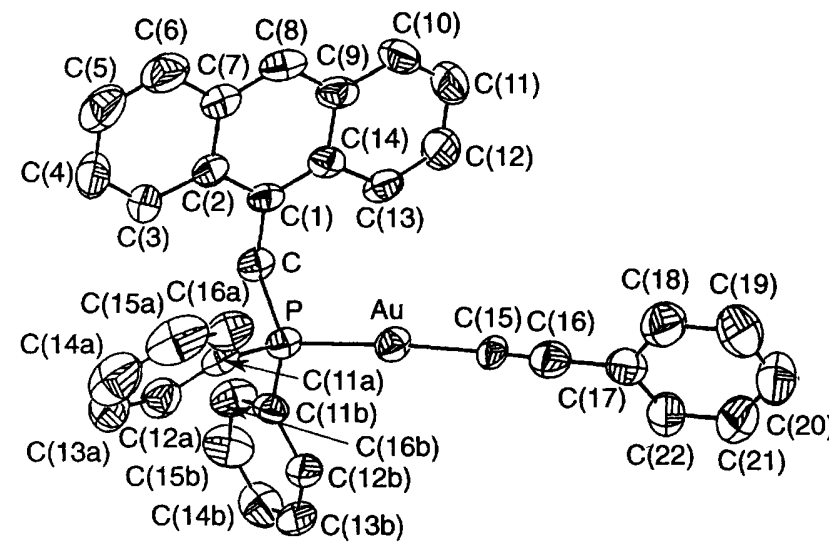

Fig. 1 A perspective view of $\left[\mathrm{Au}(\mathrm{C} \equiv \mathrm{CPh})\left(\mathrm{L}^{1}\right)\right]$. Selected bond lengths $(\AA)$ and angles $\left({ }^{\circ}\right)$ : Au-P 2.266(2), Au-C(15) 1.999(6), C(15)-C(16) $1.139(9), \quad \mathrm{P}-\mathrm{C}$ 1.839(6); P-Au-C(15) 176.0(2), Au-C(15)-C(16) 177.4(5), C-P-Au 116.9(2)

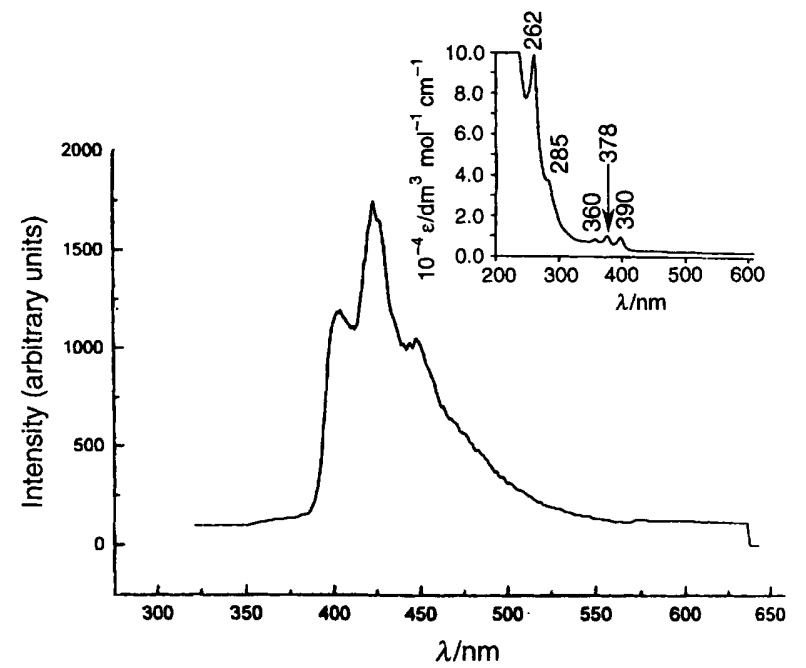

Fig. 2 Emission spectrum of $\left[\mathrm{Au}(\mathrm{C} \equiv \mathrm{CPh})\left(\mathrm{L}^{1}\right)\right]$ in dichloromethane at room temperature. Excitation at $355 \mathrm{~nm}$ insert is the UV/VIS absorption spectrum of $\left[\mathrm{Au}(\mathrm{C} \equiv \mathrm{CPh})\left(\mathrm{L}^{1}\right)\right]$ in dichloromethane $\left(1.4 \times 10^{-5} \mathrm{~mol} \mathrm{dm}^{-3}\right)$ at room temperature $\}$

the slow component reduces to $0.43 \mu$ s but there is no significant reduction in the overall emission quantum yield of the complex (0.025). This implies that the slow component is effectively quenched by oxygen and the fast component is mainly responsible for the observed steady-state emission of $\left[\mathrm{Au}(\mathrm{C} \equiv \mathrm{CPh})\left(\mathrm{L}^{1}\right)\right]$. The fast component is suggested to come from the ${ }^{1}$ (anthracene) excited state of the complex. This is supported by a time-resolved emission study. The emission spectrum recorded at a $30 \mathrm{~ns}$ delay after the laser pulse is the same as that of the fluorescence of $\mathrm{L}^{1},{ }^{8}$ while the one recorded at an $8 \mu$ s delay is similar to the emission of $[\mathrm{Au}(\mathrm{C} \equiv \mathrm{C}$ $\left.\mathrm{Ph})\left(\mathrm{PPh}_{3}\right)\right]$

Two photophysical results of $\left[\mathrm{Au}(\mathrm{C} \equiv \mathrm{CPh})\left(\mathrm{L}^{1}\right)\right]$ are noted: $(i)$ the slow component of the emission comes from the excited state of the $\mathrm{Au}(\mathrm{C} \equiv \mathrm{CPh})$ moiety with a lifetime similar to that of the emission of $\left[\mathrm{Au}(\mathrm{C} \equiv \mathrm{CPh})\left(\mathrm{PPh}_{3}\right)\right](6.0 \mu \mathrm{s})^{5 a}$ and $(i i)$ there is a drastic difference in the fluorescence quantum yields of the anthracene moiety in $\left[\mathrm{Au}(\mathrm{C} \equiv \mathrm{CPh})\left(\mathrm{L}^{1}\right)\right]$ and in $\mathrm{L}^{1}$ (emission quantum yield measured in $\mathrm{CH}_{2} \mathrm{Cl}_{2}$ is 0.17 ). Point (i) suggests that there is virtually no or very slow intramolecular energy transfer from the triplet excited state of the $\mathrm{Au}(\mathrm{C} \equiv \mathrm{CPh})$ moiety to the singlet $\left[{ }^{3} \mathrm{Au}(\mathrm{C} \equiv \mathrm{CPh})^{*} \longrightarrow{ }^{1}\right.$ (anthracene) $\left.{ }^{*}\right]$ and triplet $\left[{ }^{3} \mathrm{Au}(\mathrm{C} \equiv \mathrm{CPh})^{*} \longrightarrow{ }^{3}\right.$ (anthracene) $\left.{ }^{*}\right]$ excited states of the anthracene. Either energy transfer to the triplet excited state of the $\mathrm{Au}(\mathrm{C} \equiv \mathrm{CPh})\left[{ }^{1}\right.$ (anthracene $\left.) \longrightarrow{ }^{3} \mathrm{Au}(\mathrm{C} \equiv \mathrm{CPh})\right]$ or an increase in the rate constant of the intersystem crossing from the singlet to the triplet excited states of anthracene would lead to
Table 1 Photophysical data of gold(I) chromophore-quencher complexes in acetonitrile at room temperature

\begin{tabular}{llll} 
Complex & $10^{3} \Phi_{\mathrm{em}}$ & $\tau / \mu \mathrm{s}$ & $\Delta E\left(\mathrm{R}^{+}+\mathrm{e}^{-} \rightarrow \mathrm{RN}\right) / \mathrm{V}$ \\
{$\left[\mathrm{Au}(\mathrm{C} \equiv \mathrm{CPh})\left(\mathrm{PPh}_{3}\right)\right]$} & 12 & 1.90 & - \\
{$\left[\mathrm{Au}(\mathrm{C} \equiv \mathrm{CPh})\left(\mathrm{L}^{2}\right)\right]^{+}$} & 1.0 & 0.60 & -1.28 \\
{$\left[\mathrm{Au}(\mathrm{C} \equiv \mathrm{CPh})\left(\mathrm{L}^{3}\right)\right]^{+}$} & 5.9 & 0.77 & -1.33 \\
{$\left[\mathrm{Au}(\mathrm{C} \equiv \mathrm{CPh})\left(\mathrm{L}^{4}\right)\right]^{+}$} & 8.1 & 0.95 & -1.46 \\
{$\left[\mathrm{Au}(\mathrm{C} \equiv \mathrm{CPh})\left(\mathrm{L}^{5}\right)\right]^{+}$} & 11 & 1.51 & -1.62 \\
\hline
\end{tabular}

(ii). We suggest the latter event to be due to the heavy-atom effect of the gold.

At room temperature, the emission of $[\mathrm{Au}(\mathrm{C} \equiv \mathrm{CPh}) \mathrm{L}]^{+}$ measured in acetonitrile is very similar to that of $[\mathrm{Au}(\mathrm{C} \equiv \mathrm{CPh})$ $\left.\left(\mathrm{PPh}_{3}\right)\right],{ }^{5 a}$ with lifetimes $(\tau)$ and quantum yields $\left(\Phi_{\mathrm{em}}\right)$ in the order: $\left[\mathrm{Au}(\mathrm{C} \equiv \mathrm{CPh})\left(\mathrm{L}^{2}\right)\right]^{+}<\left[\mathrm{Au}(\mathrm{C} \equiv \mathrm{CPh})\left(\mathrm{L}^{3}\right)\right]^{+}<$ $\left[\mathrm{Au}(\mathrm{C} \equiv \mathrm{CPh})\left(\mathrm{L}^{4}\right)\right]^{+}<\left[\mathrm{Au}(\mathrm{C} \equiv \mathrm{CPh})\left(\mathrm{L}^{5}\right)\right]^{+}$

In order to examine the photophysical processes occurring in these gold(I) chromophore-acceptor complexes, a study of the quenching of the emission of $\left[\mathrm{Au}(\mathrm{C} \equiv \mathrm{CPh})\left(\mathrm{PPh}_{3}\right)\right]$ by a series of pyridinium acceptors $\S$ was undertaken. By fitting the quenching rate constants and the reduction potential of the pyridinium acceptors to the Rehm-Weller equation, ${ }^{9}$ the excited-state reduction potential $E^{\circ}\left[\mathrm{Au}(\mathrm{C} \equiv \mathrm{CPh})\left(\mathrm{PPh}_{3}\right)^{+/ 0^{*}}\right]$ was found to be $-1.73 \mathrm{~V}$ vs. SCE (saturated calomel electrode $)$. Since the $\left[\mathrm{Au}(\mathrm{C} \equiv \mathrm{CPh}) \mathrm{PPh}_{2} \mathrm{O}-\right]$ chromophore has a nearly identical structure to that of $\left[\mathrm{Au}(\mathrm{C} \equiv \mathrm{CPh})\left(\mathrm{PPh}_{3}\right)\right]$, its excited state is also a powerful reductant with a reduction potential $\left[E\left(\mathrm{Au}^{+} / \mathrm{Au}^{*}\right)\right]$ close to $-1.73 \mathrm{~V}$. We anticipate that electron transfer from the excited state of the $[\mathrm{Au}(\mathrm{C} \equiv \mathrm{CPh})]$ moiety to the pyridinium acceptor is as shown below.

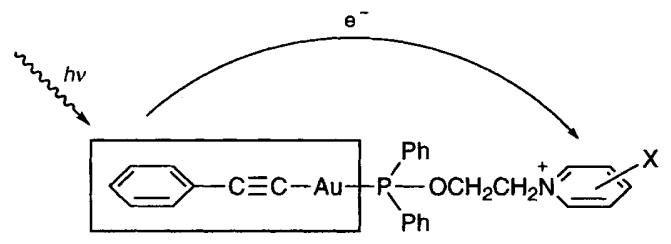

Thus, the change in emission lifetimes and quantum yields along the series $[\mathrm{Au}(\mathrm{C} \equiv \mathrm{CPh}) \mathrm{L}]^{+}$(Table 1) could be accounted for by the change in the driving force of the photoinduced intramolecular electron-transfer reactions. That $[\mathrm{Au}(\mathrm{C} \equiv \mathrm{C}$ $\left.\mathrm{Ph})\left(\mathrm{L}^{2}\right)\right]$ has the shortest emission lifetime is understandable in view of the least cathodic $E^{\circ}(-1.28 \mathrm{~V})$ of the $\mathrm{L}^{2}$ acceptor.

Variable-temperature emission-lifetime measurements have been carried out on solid samples of the $[\mathrm{Au}(\mathrm{C} \equiv \mathrm{CPh}) \mathrm{L}]^{+}$ complexes in the temperature range $30-60 \mathrm{~K}$. The estimated $\Delta E_{\mathrm{a}}$ values were determined by fitting $1 / \tau v s . T$ to the Arrhenius equation $1 / \tau=A \mathrm{e}^{-\Delta E_{a} / R T}$. The small magnitude of $\Delta E_{\mathrm{a}}$ for $\left[\mathrm{Au}(\mathrm{C} \equiv \mathrm{CPh})\left(\mathrm{L}^{2}\right)\right](0.11),\left[\mathrm{Au}(\mathrm{C} \equiv \mathrm{CPh})\left(\mathrm{L}^{3}\right)\right](0.02)$ and $[\mathrm{Au}-$ $\left.(\mathrm{C} \equiv \mathrm{CPh})\left(\mathrm{L}^{5}\right)\right]\left(0.05 \mathrm{kcal} \mathrm{mol}^{-1}\right.$, cal $\left.=4.184 \mathrm{~J}\right)$, respectively, is not unexpected for intermolecular electron-transfer reactions.

§ The pyridinium quenchers used in this work included $N N^{\prime}$ dimethylpyridinium, 3-amido-, 4-cyano-, 4-methoxycarbonyl-, 2,6dimethyl- and 2,4,6-trimethyl- $N$-methylpyridinium, $N$-ethylpyridinium, 4-amido- $N$-ethylpyridinium and 3-amido- $N$-benzylpyridinium hexafluorophosphate.

- The quenching rate constants were corrected for diffusion effects by the equation: $1 / k_{\mathrm{q}}=1 / k_{\mathrm{d}}-1 / k_{\mathrm{d}}$, where $k_{\mathrm{d}}$ is the diffusion-limited rate constant $\left(2.0 \times 10^{10} \mathrm{dm}^{3} \mathrm{~mol}^{-1} \mathrm{~s}^{1}\right)$. The non-linear least-square fits of $\ln k_{\mathrm{q}^{\prime}} v s . E^{0}\left(\mathrm{Q}^{0 /+}\right)$ using the equation $\ln k_{\mathrm{q}^{\prime}}=\ln K \mathrm{kv}-\Delta G / 2-$ $\left[(\Delta G / 2)^{2}+(\lambda / 4)^{2}\right]^{\frac{1}{2}}$ [where $K$ is approximately $1-2 \mathrm{dm}^{3} \mathrm{~mol}^{-1}, \kappa$ is the transmission coefficient, $v$ is the nuclear frequency, $\lambda$ is the reorganization energy for electron transfer and $\Delta G$ the standard freeenergy change of the reaction which is given by the equation: $\Delta G=E^{\circ}$ $\left.\left(\mathrm{Au}^{+} / \mathrm{Au}^{*}\right)-E^{\circ}\left(\mathrm{Q}^{+} / \mathrm{Q}^{\circ}\right)\right]$ gave $E^{\circ}\left(\mathrm{Au}^{+} / \mathrm{Au}^{*}\right)$ to be $-1.73 \mathrm{~V} v$. SCE. 


\section{Acknowledgements}

We acknowledge support from the Hong Kong Research Grants Council and the University of Hong Kong.

\section{References}

1 V. Balzani and F. Scandola, Supramolecular Photochemistry, Ellis Horwood, New York, 1991.

2 T. J. Meyer, Acc. Chem. Res., 1989, 22, 163; C. K. Ryu, R. Wang, R. H. Schmehl, S. Ferrere, M. Ludwikow, J. W. Merket, C. E. L. Headford and C. M. Elliott, J. Am. Chem. Soc., 1992, 114, 430; E. H. Yonemoto, G. B. Saupe, R. H. Schmehl, S. M. Hubig, R. L. Riley, B. L. Iverson and T. E. Mallouk, J. Am. Chem. Soc., 1994, 116, 4786 .

3 P. Chen, T. D. Westmoreland, E. Danielson, K. S. Schanze,

D. Anthon, P. E. Neveux, jun. and T. J. Meyer, Inorg. Chem., 1987 ,
26, 1116; K. S. Schanze, D. B. MacQueen, T. A. Perkins and L. A. Cabana, Coord. Chem. Rev., 1993, 122, 63.

4 L. S. Fox, M. Kozik, J. R. Winkler and H. B. Gray, Science, 1990, 247, 1069; R. S. Farid, I. J. Chang, J. R. Winkler and H. B. Gray, J. Phys. Chem., 1994, 98, 5176.

$5(a)$ D. Li, H. Xiao, C. M. Che, W. C. Lo and S. M. Peng, J. Chem. Soc., Dalton Trans., 1993, 2929; (b) S. J. Shieh, H. Xiao, S. M. Peng and C. M. Che, J. Chem. Soc., Dalton Trans., 1994, 3067; (c) C. M. Che, H. K. Yip, W. C. Lo and S. M. Peng, Polyhedron, 1994, 13, 887 (d) B. C. Tzeng, W. C. Lo, C. M. Che and S. M. Peng, Chem. Commun., 1996, 181.

6 E. J. Cabe, Y. Le Page, J. P. Charland, F. L. Lee and P. S. White J. Appl. Crystallogr., 1989, 22, 384.

7 M. I. Bruce and D. N. Duffy, Aust. J. Chem., 1986, 39, 1697.

8 C. W. Chan, Ph.D. Thesis, the University of Hong Kong, 1993.

9 D. Rehm and A. Weller, Isr. J. Chem., 1970, 8, 259.

Received 1st May 1996; Communication 6/03074B 